\title{
ЗАСТОСУВАННЯ ІНТЕРНЕТ-ТЕХНОЛОГІЙ В НАВЧАЛЬНОМУ ПРОЦЕСІ ПРИ ПІДГОТОВЦІ МЕДИЧНОЇ СЕСТРИ
}

\author{
В. О. Рижковський
}

Рівненський державний базовий медичний коледж

У статті проаналізовано значення і можливості глобальної мережі «Інтернет» при підготовці висококваліфікованої медсестри, а також фактори, що сприяють застосуванню даного виду технологї.

\section{USE OF INTERNET TECHNOLOGIES IN EDUCATIONAL PROCESS FOR NURSES' EDUCATION}

\author{
V. O. Ryzhkovskyi \\ Rivne State Basic Medical College
}

\begin{abstract}
The article is devoted to the importance and opportunities of the global «Internet» in the process of education of nurses to master definite skills, as well as problems and factors contributing to the use of this type of technology
\end{abstract}

Вступ. Сучасний етап розвитку суспільства характеризується переходом до всеохоплюючої інформатизації усіх соціальних інституцій і процесів, пов' язаних із формуванням інформаційних ресурсів і передачею знань. На сьогодні Інтернет - це практично нескінченний інформаційний ресурс, він є всесвітнім джерелом знань, глобальним і загальнодоступним за своєю суттю. Процес інтенсивного розвитку Інтернет-технологій привів до широкого використання глобальної мережі як ефективного інструменту навчання, який здобуває все більшу популярність у багатьох країнах світу [1, 2].

Метою роботи було дослідження значення і процесу використання Інтернет-технологій в системі вищої сестринської освіти.

Основна частина. Людство неминуче вступає в інформаційну епоху. У глобальному розумінні в процесі формування самодостатнього суспільства значна роль належить інформації, освіті та формуванню практичних навичок. Адже саме вони $є$ дієвими засобами поширення коректної

(C) В. О. Рижковський, 2014 інформації про кращі технології та досвід, що сприяють досягненню ефективності в масштабах суспільства. Серед основних задач освіти виділяють забезпечення становлення і розвиток інформаційної культури особистості та підвищення іï інформаційної свободи, тобто можливість досліднику отримувати необхідну для навчання інформацію, професійну діяльність, а також виражати свою точку зору з приводу тих чи інших явищ життя. Дослідником називають того, хто здійснює пошук нової інформації заради пізнання навколишнього світу: розв'язує нетипову проблемну ситуацію, вивчає об'єкти, проводить експерименти, отримує рішення, обговорює результати 3 іншими та оцінює власну діяльність.

Саме Інтернет-технології відповідають таким вимогам сьогодення. У жодній традиційній бібліотеці неможливо знайти такої кількості інформації, як у глобальній мережі, а тому навчальна і пошуково-дослідна діяльність не може повноцінно здійснюватись без використання мережі «Інтернет». Завдяки Інтернету все більше стає джерел інформації доступної тільки в електронній формі 
(бібліографрічні, реферативні, повнотекстові та фактографічні бази даних, електронні журнали, Інтернет-конференції тощо), причому їхня питома вага у світовому інформаційному потоці стрімко зростає. І ці джерела постійно поповнюються все новими і новими знаннями, поєднуючи ї, що дає можливість використовувати необхідну інформацію при самостійній роботі студентів, реалізаціі індивідуального підходу до навчання та пошуково-творчої діяльності.

Інтернет-технології- це технології створення і підтримки різних інформаційних ресурсів у комп'ютерній мережі «ннтернет»: сайтів, блогів, форумів, чатів, електронних бібліотек та енциклопедій. Сучасні Інтернет-технології-цей електронна пошта, теле- і відеоконференції. В основі Інтернету та Інтернет-технологій лежать гіпертексти і сайти, що розміщуються в глобальній мережі «нтернет» або в локальних мережах електронних обчислювальних машин (ЕОМ).

Гіпертексти - це тексти з гіперпосиланнями на інші тексти, розміщені в Інтернеті або локальній мережі EOM. Для запису гіпертекстів використовується мова розмітки гіпертекстів $\mathrm{HTML}$, що сприймається всіма браузерами (Web-оглядачами) на всіх персональних комп'ютерах. Мова HTML є міжнародним стандартом, тому всі гіпертексти однаково сприймаються і відображаються на всіх персональних комп'ютерах в усьому світі. Для підготовки гіпертекстів зазвичай використовуються візуальні гіпертекстові редактори, у яких відразу видно як буде виглядати гіпертекст на EOM і можлива вставка гіперпосилань на сайти в Інтернеті. Одним з найкращих візуальних гіпертекстових редакторів $\epsilon$ вільний офісний редактор Writer у вільному офісному пакеті Open Office.

Інтерактивні сайти-це сайти, в яких використовуються інтерактивні гіпертекстові підпрограми, що дозволяють вести діалог з користувачами EOM, підключених до мережі ЕОМ. Гіпертекстові підпрограми включаються до гіпертексту разом із гіпертекстовими формами і підпрограмами, які називаються скриптами. Для запису гіпертекстових підпрограм (гіпертекстових скриптів) часто використовується мова JavaScript, що є розширенням мови розмітки гіпертекстів HTML.

Мова JavaScript $\epsilon$ розширенням розмітки гіпертекстів HTML і з цих причин інтерпретатор мови JavaScript вбудований у всі браузери і всі гіпертекстові редактори. Мова JavaScript $€$ міжнарод- ним стандартом. 3 цієі причини інтерактивні програми на мові JavaScript однаково виконуються на всіх комп'ютерах у світі. Більше 60 \% програм у світі написано на мові гіпертекстових скриптів JavaScript. Програми на JavaScript - найкращий приклад відкритого доступу в Інтернет - ї можна читати, виконувати і модифікувати будь-який дослідник, знайомий з мовою програмування на JavaScript.

Локальна мережа ЕОМ - це спільне приєднання декількох окремих комп'ютерів (робочих станцій) до одного каналу передачі даних. Мережеві технології $\epsilon$ тією ланкою, яка дозволила об'єднати результати роботи багатьох автономних користувачів та надати доступ до цих результатів всім, хто в них зацікавлений. Тому напрями розвитку мережевих технологій без сумніву визначатимуть напрями розвитку інформаційних технологій в цілому. Саме розвиток мережевих технологій диктуватиме основні напрями розвитку апаратного і програмного забезпечення.

Зараз можна виділити такі основні напрями використання мережевих технологій: технологія сховищ даних; WАР-технологіі (способи вийти до ресурсів Інтернет через мобільний телефон) [4]; комп'ютерна телефонія; дата-центри.

Комп'ютерна телефонія - це дисципліна застосування можливостей комп'ютера для генерації і прийому телефонних викликів та інших повідомлень, зразок факсимільного зв'язку, а також транзакцій в мережах загального користування, в тому числі й мережі «нттернет». Даний термін охоплює широкий спектр технологій: інтеграцію через локальну мережу комп'ютер-телефон, інтерактивну обробку мови, операторські Callцентри, мовну пошту, ідентифікацію мови, реформування текст-мови, одночасну передачу мови та іншої інформації [6].

Дата-центр являє собою сукупність спланованих певним чином територій, зовнішніх майданчиків (анклавів), будівель, приміщень зі встановленими інженерними системами забезпечення та обслуговуючим персоналом, що утворюють загальний фізичний простір і технологічне середовище для розміщення комп'ютерів, електронних та інших засобів прийому, передачі, обробки, зберігання інформації забезпечують задану ступінь доступності (готовності), розміщеного обладнання в заданому режимі функціонування [3].

У зв'язку з активним впровадженням у навчальний процес Інтернет-технологій змінилися освітні 
цілі, які значною мірою тепер спрямовані на формування і розвиток здібностей студентів до самостійного пошуку, збору, аналізу та подання інформації. Сучасні вищий навчальний заклад і навчальний процес припускають впровадження нових форм роботи і передбачають нові ролі: викладача як консультанта і студента - як активного мотивованого дослідника, творчо і самостійно працюючого над вирішенням навчальної задачі, що широко використовує Інтернет-технології для отримання необхідної інформації.

Системне впровадження комп'ютерних технологій - потреба, яка вже давно назріла в медичній освіті й в сестринській зокрема. Застосування сучасних Інтернет-технологій у навчанні $є$ безпрецедентним для активізації пізнавальної діяльності та ефективним у викладанні і впровадженні в дисципліни сестринського профрілю елементів пошукової роботи. Це дозволяє залучити студентів до самостійної діяльності, неодноразово посилюючи можливості аналізу та синтезу явищ і процесів. Використання Інтернету в пошуково-дослідній роботі дозволяє виконати цю задачу [5].

Впровадження елементів пошукової роботи на таких дисциплінах, як медична хімія, медична біологія, фармакологія, сестринська справа, медсестринство в терапіі, хірургіi, акушерстві і гінекології та інших дозволяє вирішити не лише прагматичні ситуаційні задачі, але й створити умови мотиваційних факторів, необхідних для подальшої професійної підготовки, розвивати клінічне мислення. Можливість впровадження пошукової роботи різного рівня складності з урахуванням індивідуальних особливостей сприйняття студентів дозволяє зняти напруження, що позитивно впливає на їх емоційний стан. Також у процесі пошукової роботи студенти проходять через стадію вільного та свідомого відтворення матеріалу, що сприяє створенню відповідних внутрішніх мотивів, а це, у свою чергу, допомагає виявити ступінь мезальянсу між інформацією, яку необхідно засвоїти, та фактично засвоєною.

Мотивація студентів у процесі пошукової роботи при впровадженні Інтернет-технологій постійно зростає. Методика створення активної мотивації з боку викладача формує уявлення у студентів про роль цих дисциплін у майбутній діяльності та допомагає у розв'язанні конкретних професійних задач, вона $є$ найрезультативнішою.

Відомо, що пошук інформації в мережі «Інтернет» неможливий без спеціальних механізмів, які допомагають студенту знайти в цьому безмежному просторі потрібну інформацію. У середині 70 років з'явились так звані інформаційно-пошукові системи, які й досі постійно удосконалюються. Найбільш популярними й ефективними на сьогодні $є$ такі інформаційно-пошукові системи, як: Rambler, Meta-Ukraine, Yahoo, Lycos, AltaVista, Infoseek, WAIS та ін.

Варто згадати і про такі пошукові системи, що мають своє поле длявведення запиту, але не обробляють його, а розсилають по всіх пошукових машинах, з якими користувач хотів би працювати. Дочекавшись відповіді від усіх пошукових систем, ці програми надають користувачу можливість скористатися заданою кількістю посилань, отриманих від кожного пошукового сервера. Такі програми з'явилися недавно й отримали назву позначоксистем. ІІхнє число зовсім невелике, і на сьогодні відомі лише такі системи, як: Metacrawler, Savvy, Metasearch i Dogpile.

Також існують пошукові каталоги, які організовані за тим самим принципом, що й тематичні каталоги бібліотек. На основній сторінці пошукового каталогу подано скорочений список великих тематичних категорій, наприклад таких, як освіта (Education), наука (Science) та ін. Кожний запис у списку категорій - це гіперпосилання, яке відкриває наступну сторінку пошукового каталогу, де ця тема представлена докладніше. Елементами найнижчого рівня є посилання на окремі Web-сторінки і сервери разом із стислим описом ї змісту. Продовжуючи занурення в тему, можна дійти до цього списку Web-сторінок і вибрати той ресурс, який краще придатний для розв'язання конкретної інформаційно-пошукової задачі.

Проблемою залишається те, що активне використання комп'ютерних технологій вигідно вирізняє європейського студента від нашого, європейську медсестру від вітчизняної. І це насправді так - за кордоном вже тривалий час здобуття медичної освіти та виконання професійних обов' язків в охороні здоров'я немислиме без комп'ютера. Саме тому в Україні розпочато реалізацію широкомасштабної і планової політики з формування медичного освітянського інформаційного простору, ядром якого $є$ Web-портали вищих медичних навчальних закладів України. Впродовж попереднього часу сформовано головні елементи структури Web-сайтів, на яких, окрім загальної інформації про навчальний заклад, ведеться значна робота з формування та розміщення виклада- 
чами електронних навчально-методичних матеріалів й з медсестринства зокрема. Це надзвичайно актуально, оскільки підручник у паперовому вигляді в момент свого виходу вже застаріває на 5 років, тоді як електронні матеріали для підготовки до занять, розміщені викладачами на Webпорталі містять найсвіжіші дані медичної (сестринськоі) науки та практики.

Висновок. Успішність використання Інтернеттехнологій в навчальному процесі має досягатися шляхом підвищення кваліфікації викладацького

\section{ЛITEPATУРA}

1. Гагин А. СервисыИнтернет[Электронныйресурс]/ А. Гагин. - Режим доступу: http://www.computermuseum.ru/technlgy/ji96071.html.

2. Глинський Я. М. Інформаційні технології [Текст] / Я. М. Глинський. - Львів : Деол, 2004. - 264 с.

3. Дата-центр [Електроннийресурс] / Режим доступу: http://uk.wikipedia.org/wiki/Дата-центр

4. Технологія WAP [Електронний ресурс] / Режим доступу: http: / / www.mobile-talk.ru/termin-14.html. складу на спеціальних курсах і семінарах, розв'язання проблеми мотивації студентів, розширення світогляду та інтелектуальних можливостей студентів, а також при відповідному матеріальнотехнічному забезпеченні навчального закладу. При цьому очікується підвищення інтенсивності роботи, ï̈ організованості, якості знань, самостійності, предметної новизни, синтетичних і аналітичних здібностей майбутніх медичних сестер тощо.

5. Проблема мотивації студентів у процесі пошуковоїроботи привикладанні хіміко-фармацевтичних дисциплін з використанням інформаційних технологій / Н. М. Толмосова, В. В. Галиця, Т. М. Галяміна [таін.] // Запорізький медичний журнал. - 2012. - № 6. - С. 75.

6. Що таке комп'ютерна телефонія? [Електронний ресурс] / Режим доступу: http://e-ogo.com.ua/shhotake-komp-yuterna-telefoniya

Отримано 16.04.14 